\title{
Remembering Les Cleveland
}

A Profile by Michael Jackson

As Michael Jackson notes in this profile, Les (Francis Leslie) Cleveland (1921-2014) was a man of many parts. As a New Zealand journalist, political scientist specializing in the media and a photographer, Cleveland is clearly a person of interest for a journal looking at New Zealand's media and art history. An account of Cleveland's life could alight on any one of a number of aspects but in this profile the author focuses on his early experiences in the Great Depression and the Second World War as the backstories central to understanding Les Cleveland. 
Recalling his High School years in the 1930s, Les Cleveland described himself as irritated by the jingoism of those in authority, and drawn to independently minded individuals, no matter how heretical, cranky and subversive they were. Even as a teenager, Les cultivated a persona that blended the trickster and the handyman. As he put it, 'A cross between Charlie Chaplin and Bob Semple.' A self-taught builder, welder, motor mechanic, and electrician. A poet, songwriter and singer, journalist and political scientist. A mountaineer, master photographer and self-styled literary blacksmith.

Almost every published account of Les Cleveland cites his eclectic talents and multiple identities. Rarely, however, is his experience of growing up during the Great Depression and serving as an infantryman in the Second World War explored in any depth. It is these backstories I am concerned with in this essay, for I am convinced that almost everything Les became known for, including his photographs of old buildings and abandoned mines, his DIY attitude, and his skills in scavenging, salvaging, and surviving were born of his early experiences. His book Dark Laughter ${ }^{3}$ recounts the ways in which soldiers use gallows-humor, letters home, subversive stories, ribald songs, wild escapades, and drinking bouts to ritualistically overcome the soul-destroying effects of mechanical routine and violent combat. 'Military folklore,' Les observes, is 'an expression of resistance to the idea of powerlessness. It provides strategies for trying to get one's experiences into some manageable framework, something that will make sense of it. Otherwise, I think you'd have to admit that it was chaos and you were being blown about in it like a leaf in a storm.'4 Though written as a general account of soldiers' experiences, Dark Laughter is also an oblique commentary on its author's struggle with traumatic loss. 'I've always tended to look back' Les once wrote. 'I've always been interested in leftovers and survivals. ${ }^{5} \mathrm{His}$ photographs of ghost towns, his archive of old newspapers, his collection of machine parts, and the house he built in Brooklyn to withstand earthquakes, are all of a piece - evidence of a battle to which we can all relate, against amnesia and vulnerability.

I first met Les at a party on Oriental Parade in 1965. Our girlfriends hit it off, and Les and I were thereby brought together. I was a relief teacher in the Wairarapa at the time, and spent only my weekends in Wellington, so it wasn't until late in the year that Les and I became better acquainted. Having rented a house in Featherston, Pauline and I invited Les and Mary, together with mutual friends, Vincent O'Sullivan and his wife, Tui, to spend a week with us.
Thirty years later, these idyllic days were vividly brought back to mind when I was staying with Les and Mary while researching the life and times of Joseph Pawelka. ${ }^{6}$ One evening, Les dug out a reel of film he'd shot in the southern Wairarapa 1965. He'd never developed it, but now decided to see if the images had survived.

The photos that emerged from his darkroom were grainy, gray and scratched. This only increased their power. It was like opening up a grave and finding no evidence of decay. The shock of seeing these snapshots overwhelmed me. They were windows into a time I had reworked in memory. But now a faithful likeness of Pauline, who died in 1983, had reappeared, and it was like a door opened for a moment onto a field of light.

Here we are, sitting outside the Lake Ferry hotel in the sun except for Mary, who must have taken the photo. In another photo we are in the bar holding glasses of beer and peering at Mary behind the camera.

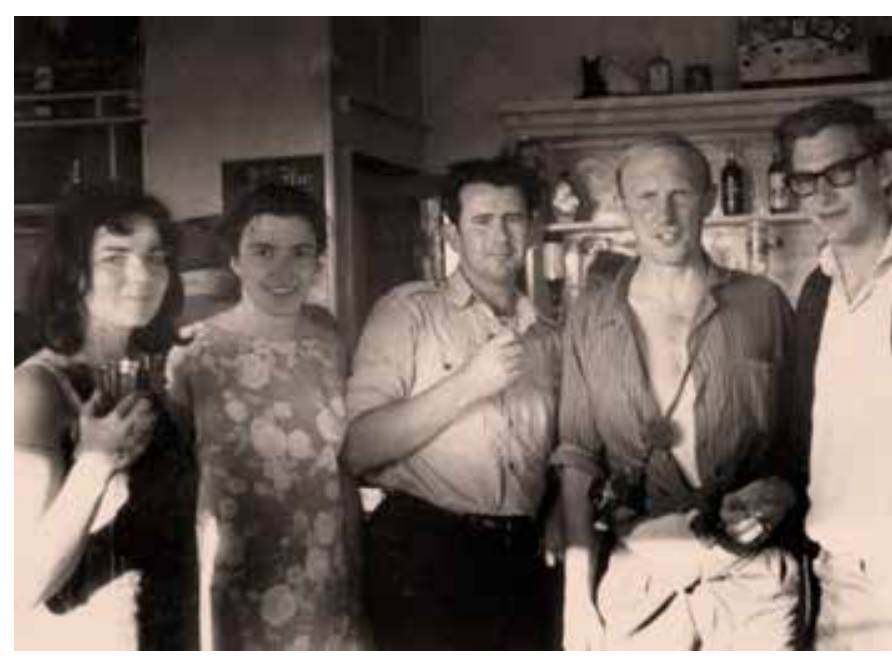

From left to right - Pauline Harris, Tui O'Sullivan, Vincent O'Sullivan, Les Cleveland, Michael Jackson. Photo credit: Mary Cleveland. Photo from the author's collection.

During my years abroad, I revisited Wellington annually, always calling on Les and Mary to hear news of their trips to Washington D.C. and Las Vegas, or their summers in south Westland. One of the last times I saw Les was in 2009. After travelling around the South Island, researching a book on the theme of firstness, ${ }^{7}$ I crossed Cook Strait in stormy weather and drove directly from the ferry terminal to Brooklyn where I found 
Les and Mary finishing a late lunch. The walls were covered with Les's photographs of ruined boarding houses in Arizona, abandoned diggings in Nevada and Westland, and wooden buildings whose original use could only be guessed at. Postcards from Las Vegas. The pot-bellied stove. Almost the first thing I said was that no time seemed to have passed since I was last there.

Ever the realist, Les declared that none of us was getting any younger, and he described how, a couple of months ago, he had been lugging an armful of logs up from below the house when he lost his footing and fell. 'It's a fifteen-foot flight of concrete steps,' Les said. 'On the top step I forgot to shift my weight forward enough and began falling backward. Something in me took over, as it invariably does in a crisis, so that I somehow turned completely, before landing face down with one arm clutching at the wall for support. I did not do this; my instincts did. Unfortunately, it wasn't enough to save me from a broken wrist and skull fracture.'

'I thought he was dead,' Mary said. 'That's what my instincts told me.' And she related how Les was hospitalized only to discharge himself two days later, preferring to take care of himself and recover at home.

'It was a reprieve,' Les said. 'We both thought, this is it. But there was no magic moment, my life replayed in a split second. No tunnel of light, any of that stuff. But in the days that followed, I kept thinking of a bizarre incident during the war when I almost lost my life.

'We were dug in around, as well as occupying, a large house.

Under cover of darkness, the Germans brought up a fixed gun, and its first shell scored a direct hit on the house. I would normally have been with Podge Hoskins at a machine-gun post at an upper floor window, but l'd been detailed to the kitchen and was frying up tinned bacon and egg powder when the shell hit. There was an ear-splitting explosion, splinters of wood, debris, dust. But in the midst of this maelstrom and the screams from the front room, I covered the frying pan with a tea towel and placed it carefully under the table. Only then did I go to the aid of the men in the other room. I had to kick down the door to get in. Almost everyone had been torn apart. Some were dead, others dying. The scene was as gruesome as any I had witnessed. Podge upstairs had been killed instantly. Yet I survived. And afterwards, what I could not get over was that moment with the frying pan. How I could go on as though nothing had happened. Was it denial of a reality I could not deal with? Was it my military training?

Mary suggested we move to the front room where the rain- streaked windows overlooked a sodden sports field and the distant Orongorongos.

I felt a little like the main character in John Mulgan's Man Alone, who encounters Johnson in a Breton fishing village and repairs with him to a local café where they eat prawns, drink cheap red wine and get to talking about the war.

'You were in the Great War,' I said. 'Tell me about that.' 'I've been in all the wars,' Johnson said, 'but I couldn't tell you anything about it.'

'You won't talk about it?'

'I couldn't tell you anything even if I did. It wasn't anything. You wouldn't understand it unless you saw it. If you did see it, you wouldn't understand it.'

It was very hot and stifling in the café, though as we sat there it began to grow quieter, and the smell of fish and cooking-oil was mixed with tobacco smoke.

'I couldn't tell you about the war,' Johnson said. 'It wasn't a lot different from anything else. I could tell you worse things about the peace.'

'What was the peace?'

'That was the bit in between.

'Worse things?'

'Truer things.'

And so I said to him, not wanting to move and quite ready to listen: 'Tell me about the peace then.'

In 1974, when Pauline and I were living in the Manawatu, Les and Mary were frequent visitors. Though Les seldom drank alcohol, his Mark Twain-like skill in puncturing pretension, his spirited recitals of Beowulf in the Anglo-Saxon, or the alacrity with which he would break into singing unprintable soldiers' songs, was as entertaining as it was enviable. But like the peace of which Mulgan speaks, the shadows of war were ever present. For dinner one night, I prepared a spaghetti Bolognese only for Les to confess he couldn't eat it. He had an aversion to garlic. I gave the incident little thought, but sometime later Mary confided to Pauline that the New Zealanders in Italy were often so far ahead of their supply lines that they were driven to scavenge for food and shelter. Desperation sometimes drove them to steal food at gunpoint from the tables of Italian peasants, and to pillage wooden altar pieces in local chapels to use as firewood on winter nights. 
Unsettling memories were revived by the smell of garlic, and like many traumatized soldiers Les had his fair share of things he avoided talking about. Although I never pressed him on such matters, it was not long before I realized that his writings were increasingly about them.

In his Introduction to The Iron Hand (1979), a compilation of New Zealand soldiers' poems from World War Two, Les mentions a close friend, Ted Scherer, who died of shrapnel wounds during the last offensive of the Italian campaign. Scherer was only inches away from Les when he was hit.

Shrapnel-ripped and lifeless on the Santerno

Helmet tilted back into the lacerated earth,

Face twisted up for one last

Regretful look at the murderous sky

It was April 10th 1945. That morning, Ted Scherer had looked north and told Les, 'When it's over we'll celebrate - we'll climb the highest point in the Alps.' After recovering in hospital from his own wounds, Les went into training in the Dolomites by doing some rock climbing.

'But I could not persuade anyone in the battalion to accompany me on an expedition to Mont Blanc. By this time, we were in bivouacs at Lake Trasimeno, near Rome. I set out from there on a goods train which took me to Milan, and I travelled by a variety of means through the mountains to Courmeyeur where I was able to persuade a young Italian refugee to join me in the ascent. It was late in the season and the climb was arduous, particularly as our equipment was improvised and we suffered a good deal from inadequate food as well as from cold, exposure and exhaustion. ${ }^{10}$

Every step of the way, Les was thinking of his friend and all the mountains they might have climbed together, 'and all the other friends of friends, shuffling, legions of them, in long, suffering lines across the mortuary of Europe.' What good being alive, when those who meant the world to you were dead? "Kaput", said the young refugee, who had found 'sympathy and courage enough to march in a dead man's steps.' "Guerra kaput! Jawhol", the survivor mumbled, "Guerra kaput!"

Six hours up an icefall on the south face, Les and his companion encountered a line of fresh tracks that drew them across the mountain's shoulder to a high-altitude, unlined metal hut. Inside, they found a party of German-speaking Swiss, laughing and talking over their experiences on the tourist route from Chamonix. The amiable holidaymakers were casually helping themselves to food from their rucksacks, 'innocent of the terror gnawing at their frontiers.' In broken German, Les enlightened them.

We are climbers, British soldiers.

They look disbelievingly at our improvised gear Wehrmacht rucksacks, Alpini boots, Kaiapoi woolen Jerseys, caps comforter, and old army socks for gloves. What sort of army is this? Probably deserters Or escaped prisoners; maybe dangerous too. Offer them nothing.

So I pull the Luger on the fattest of the bunch No Alpine-fucking-club outing this,

Ich haben grossen hunger!

We grab a loaf of their bread and some fruit And drain a bottle of wine.

Nobody speaks: only the autumn wind

Snickers and squirms in the doorway.

Before trying the peak I pick over their parkas

And trade the best one for my military gas cape,

Then we buckle on crampons, adjust the rope

And start up the summit ridge.

After the war the Scherer family got in touch with Les and in 2008 he received a letter from Ted Scherer's daughter asking if he would write down for her everything he could remember of her father. 'It's a bit of a struggle,' Les told me. 'It isn't easy to write about war without including the gory details. The sort of things no one would want to hear about or read about if they were going to have a positive memory of their loved one. It raises questions about life and death I cannot answer, though I have pondered them for years.'

Les was 88 . He had been returning to the war for sixty years, though mostly to the experiences of others, including most recently a translation of the notebook of Helmut Metzner, a soldier in Rommel's Afrika Korps that contained occasional critiques of the Nazi regime and a crude poem in which he imagined himself having sex with Lili Marleen. When Les mentioned this project to me, he said, 'I would very much like a chat with Helmut but we know for certain he is very kaput, kaput, kaput! Still, he lives on in my files along with Charles Smith and 
others.' I was struck by this reference to files, because the real place the past lived on was in Les's memory, and I wondered whether the vital difference between Les's forays into the past and the obsessive compulsive replaying of harrowing experience that we call PTSD, was Les's ability to make his own experiences secondary to those of others, putting them first, sacrificing his story in order that theirs be told.

For traumatized New Zealand veterans, the inhibition against recounting their experiences came from without and within. A psychology of denial had its counterpart in a social conspiracy of silence that reflected a characteristically Anglo-New Zealand ethos of reticence and self-control. More pointedly, however, it reveals a reluctance to burden loved ones with harrowing stories. As Les put it, mindful of his own two sons, 'How the hell can you explain to them what's bugging you? They are in a state of innocence. It's quite difficult, I think, to expound terror and one's admission of fear to people who have not experienced any of those aspects of the world. It seems monstrous to attempt such a thing ... so you shut up about it.' Though old anxieties - of being too afraid to fight, of being a POW unable to find enough food - 'burst out in dreams and in odd behavior,' the code of the warrior keeps one's lips sealed. 'It's a deficiency to be showing a weakness. A warrior doesn't behave unheroically, he grits his teeth and puts up with various dangerous and murderous activities like Germans trying to kill him all the time. He somehow manages to control himself and keep a stern face on things.'11

'After the war,' Les writes, recalling his ascent of Mont Blanc, 'I would make many more difficult and dangerous journeys in our own mountains, but never under such emotionally disturbed and isolated circumstances. The Mont Blanc affair was a therapeutic venture into self-recovery and a wild leap into a new world of changed personal relationships; it also meant that a sense of bereavement and brooding anxiety could be thrown off in the exuberance of physical achievement. ${ }^{12}$

Nevertheless, Les admitted to having been 'neurotic' when he returned to Christchurch in 1945 and tried to settle back into civilian life. 'Fourteenth platoon suffered forty percent losses, almost as high as the Māori Battalion's, and every soldier felt the burden of this. In Christchurch I would obsessively stare at the shoes of people walking in front of me, waiting for a mine to detonate. Any loud percussive noise and I would immediately be looking for somewhere to take cover. I had to leave the city and work in the Westland bush where the only sounds were tuis and falling water. It took me three years before I felt ready to return to city life. ${ }^{13}$
I was always impressed by Les's sense of proportion and practicality, and in talking with Sierra Leoneans in the aftermath of their war it was constantly brought home to me that recovery depends more on one's ability to throw oneself into the tasks of everyday life caring for a child, making a farm, putting food on the table, sharing with those in greater need - than in one's success in seeking revenge or compensation, or wringing some meaning out of the arbitrary events that changed your life forever. Intellectual reflection has a place in our lives, to be sure, but unless it is connected to the imperatives of life in the here and now it risks becoming morbid and dissociated. In this respect, I shared with Les a contempt for the more abstract and pontifical excesses of academic discourse, and struggled to keep thought grounded in the experiences and exigencies of everyday life.

Les's intolerance of academic and political bombast also explains his steadfast refusal to participate in the writing of official history or to attend postwar ceremonies that extolled the heroic sacrifice of the fallen. A sober pragmatism informed everything he wrote on soldier's songs, poems and popular culture. 'If I were to attempt an epic of our military experiences that tried faithfully to evoke the consciousness of the ordinary soldier, I would probably relegate the formal historical details to a chronology at the back of the work in order to concentrate on things that really matter, like a concern with food, cookhouses, liquor, sex, clothing, the weather, rates of pay, equipment, loot, amusements, recreation, morale, the techniques of deviancy, how to maintain one's precious individuality and, above all, how to avoid becoming a grim statistic on one of our grisly war memorials.' ${ }^{14}$

In Les's view, combat soldiers share with civilian workers in hazardous occupations a sense of powerlessness that can only be countermanded by organizing collectively, fostering a sense of solidarity, and having recourse to mockery and dark laughter..$^{15}$ You may not be able to buck authority, disobey orders, go on strike, or escape the nightmare of knowing that an organized army is bent on killing you, but you can preserve your sense of connectedness to a world where your individuality has some value and your actions matter by writing letters home, keeping a diary, or joining forces with your mates in ridiculing the situation in which you find yourself. Mutiny or deserting are out of the question, but mocking the powers that be, protesting one's lot, turning to sexual fantasy, and venting one's frustrations in obscene songs can sometimes transform one's sense of being a victim into a sense of being able in some small measure to experience one's situation on one's own terms. To dwell on a tragedy is to risk drowning in it. 
To turn it into farce is to remain afloat, treading water as it were, even though you may be simply deferring the moment when, exhausted, you sink beneath the waves.

'This was what happened to many men,' Les said. 'The psychological casualties who returned home, haunted by what they had seen and done, hoping that silence, time and compulsive routines would heal the hidden wounds. It simply isn't possible to come home as if nothing's happened and step back into the role of Mr. Normal from Ashburton. There remains a part of you that is continuously preoccupied with questions like; how can I stop thinking about the bloke that got killed instead of me? Where is tomorrow's food coming from? Such sinister, unrelenting calculations. I visited a bloke on a farm in Taumarunui once. He had about a year's supply of baked beans, tinned vegetable stew and other stuff under the floorboards of his house, not to mention a vast quantity of wine. He'd been a prisoner of war and was determined he wasn't going to run out of food ever again. I looked on in amazement when he said, l'll just get a couple of bottles of wine, and proceeded to pull up the floorboards. He had cases of the stuff down there. But he was still living inside that cocoon of deprivation and fear and had to come to terms with it by doing things around the farm. He was always supplying. He had some troubles with the local hardware people. So he bought a sawmill and set it up on the property and milled his own timber. Instead of bringing in a contractor to root up tree stumps and do a bit of earth moving, he bought two bulldozers and had them sitting there in the shed. He was prepared for a siege. That's an extreme example of the POW mentality, but I think he had successfully coped with his experiences, even if his behavior was a bit odd. ${ }^{16}$

Of all the soldiers' poems Les collected in the postwar years, perhaps the most moving is by Charles Smith, who was among the New Zealanders ordered to hold a pass near Katerini, northwest of Mt Olympus, in order to gain time for the rest of 2NZEF, retreating from the rapidly advancing Germans. Smith's poem first appeared in the NZEF Times in August 1942. It is simply called Greece. It is about the bonds that were formed between the New Zealanders and Greek villagers during the tragic campaign of April-May 1941, in which the New Zealand force sustained 2,504 casualties before withdrawing to Crete where, in the course of its continuing retreat, 3,853 out of a total strength of 7,702 were killed.
Out of the soil comes greatness of soul ...

These, shaped by old knowledge of their jealous sod Take on unswerving courage. They belong

To trees and fields, and mountains; so to God.

So first we saw: and never bread so sweet Nor gift so free, nor welcome waking so; Kindness so laughing, quick and garlanded, Nor carnival of fortitude so gay As heart of Greece in spring, on Freedom's day.

So near the shadow!

Yet in dark retreat

Came dusty envy that they still could cry 'Kalimera, English!' and 'Goodbye!'

Hold fleeting friendship past the threat of death, Give food and shelter: even understand Our last desertion.

Do they know

How heart-remembered all their faces go?

These things are deathless, memory's cornerstone,

That rivulet that feeds the golden stream ...

Is Ag Demetrios still a mountain dream? Storks on the roof and cobbles on the street, White from Olympus faerying the pines

Where bitter snow and spring of promise meet Thyme and wild daphne.

\section{Does Kathrina wear}

A soldier's badge still braided in her hair?

Some years ago, Les read this poem in the course of a radio talk. He mentioned that, despite his best efforts, he had been unable to trace the author and presumed him dead. Within a week, Les received an indignant letter from Charles Smith saying he was not dead. He was a farmer near Whangarei, with a family, and very much alive. 
We are often surprised by what survives from the past, and what does not. And how something we carry forward into the present can become so transformed that it ceases to possess what drew us to it in the first place, what persuaded us it was worth keeping.

When Les recounted his visit to the Taumaranui farmer, he went on to say that there were many such men who could not tolerate confinement or bear to be shut up in a small space. 'Who get out on their farms and go for long walks and talk to dead companions or to God. Some carry a lot of grievances, but they keep these to themselves'.

I could not help but think of Les's own retreat in South

Westland, as remote from the madding crowd as one could wish for, and close to the mountains and bush that had always been his very present help in trouble. But why do earth, stone, trees and the sea have this power to bring us calm in troubled times?

In the Tao-te Ching (XVI), stillness is identified with one's roots, one's infancy and with the nothingness from which the teeming and myriad forms of both life and thought emerge, and to which in time they return. This original nature may be compared to a rough and unpolished stone. To contemplate it is to be returned to the pre-phenomenal ground of all being. But the manifold and changing forms of things are also worthy of contemplation, and I find it difficult to accept the fetishization of firstness or the idea that foundations are necessarily more real than anything we built on them. This is why stone implies, for me, not absolute constancy, but an image of constancy that helps one endure the vicissitudes of life, in which everything is sooner or late shattered, worn away, or reshaped by the elements with which we have to contend. From this observation arises the question of art, and of what we make of life, for while it is important to remember one's beginnings, to bear in mind from whence one came and to whom one owes one's life, it is, I think, foolish to do so at the expense of recognizing the importance of new departures in which the original material is refashioned, as it were, in one's mind's eye or in one's own hands.

On the wooden terrace of his Wellington house, Les kept, for many years, numerous river stones and boulders that he had found on his excursions into the wilds of Westland. These stones not only caught his eye; they had, in a sense, possessed him - some because of a curious blemish that he could not reconcile with processes of natural erosion, some, like greenstone, because of their geological rarity, and some because of their uncanny similarity to the contours of the human body. Les would lug these boulders down mountain gorges and through heavy bush, sometimes for days on end and often in a rucksack emptied of his personal supplies, before bringing his booty home to be burnished by rain, commented upon by friends or made the occasion for a story. When I left Wellington to pursue my Ph.D. studies at Cambridge, I would often think of Les's collection of stones and it was with considerable dismay that I discovered, on my return to New Zealand after four years abroad, that Les had enlarged the living room of his house and built, in the middle of it, a massive fireplace whose chimney consisted of these beautiful stones cemented together into something resembling a cairn. But now, having known Les for so long and sat in front of his fireplace countless times, deep in conversation about our various travels or current projects, I no longer think that the stones properly belong to the contexts from whence they came. They belong where they are. And at Harvard, I would discover in the course of long talks on early Chinese traditions with my friend Michael Puett ${ }^{17}$ that my thinking was not inconsistent with a Taoist view that sees the world as essentially (and demonically) chaotic, so that our human endeavors to create spaces of order are always transitory, and Les's river stones are destined to be once again a natural shambles on a hillside where no vestiges of his house or handiwork remain. 


\section{END NOTES}

1 Les Cleveland, 'A Course in Survival,' in Les Cleveland: Message from the Exterior, ed. Lawrence McDonald (Wellington: City Art Gallery 1998), 34-40.

2 Bob Semple was Minister of Works during World War II. He advocated making military equipment from whatever materials came to hand, building a tank from corrugated iron on a tractor base.

3 Les Cleveland, Dark Laughter: War in Song and Popular Culture (Praeger: Westport, Conn., 1994).

4 Les Cleveland in taped conversation with Michael Jackson, Wellington March 1999.

5 Cited in Athol McCredie, 'The Social Landscape,' in Witness to Change: Life in New Zealand, Photographs by John Pascoe, Les Cleveland, and Ans Westra. (Wellington: PhotoForum 1985), 52.

6 My research into the early twentieth century New Zealand fugitive was published as The Blind Impress (Palmerston North: The Dunmore Press, 1997).

7 Michael Jackson, Road Markings: An Anthropologist in the Antipodes (Dunedin: Rosa Mira, 2012).
8 John Mulgan's Man Alone (Auckland: Longman Paul, 1972).

9 Les Cleveland, The Iron Hand: New Zealand Soldiers' Poems from World War Two ) Wellington: Wai-te-Ata Press, 1979).

10 The Iron Hand, 11-12. In his poem, The Long Way Back, Les Cleveland writes of the same moment: 'A week ago the other survivors/ Carousing rowdily in Rome/Declined to join this excursion', The Iron Hand, 51.

11 Taped conversation with Michael Jackson, March 1999.

12 The Iron Hand, 12.

13 Les Cleveland, personal communication, 2009.

14 Les Cleveland, 'An Assiduous Industry,' New Zealand Books, June 1997, 15.

15 Les Cleveland, 'Soldiers' Songs: The Folklore of the Powerless,' New York Folklore, 1985, 11 $(1-4), 79$.

16 Taped conversation with Michael Jackson March 1999.

17 Michael Puett is Walter C. Klein Professor of Chinese History and Anthropology at Harvard University.

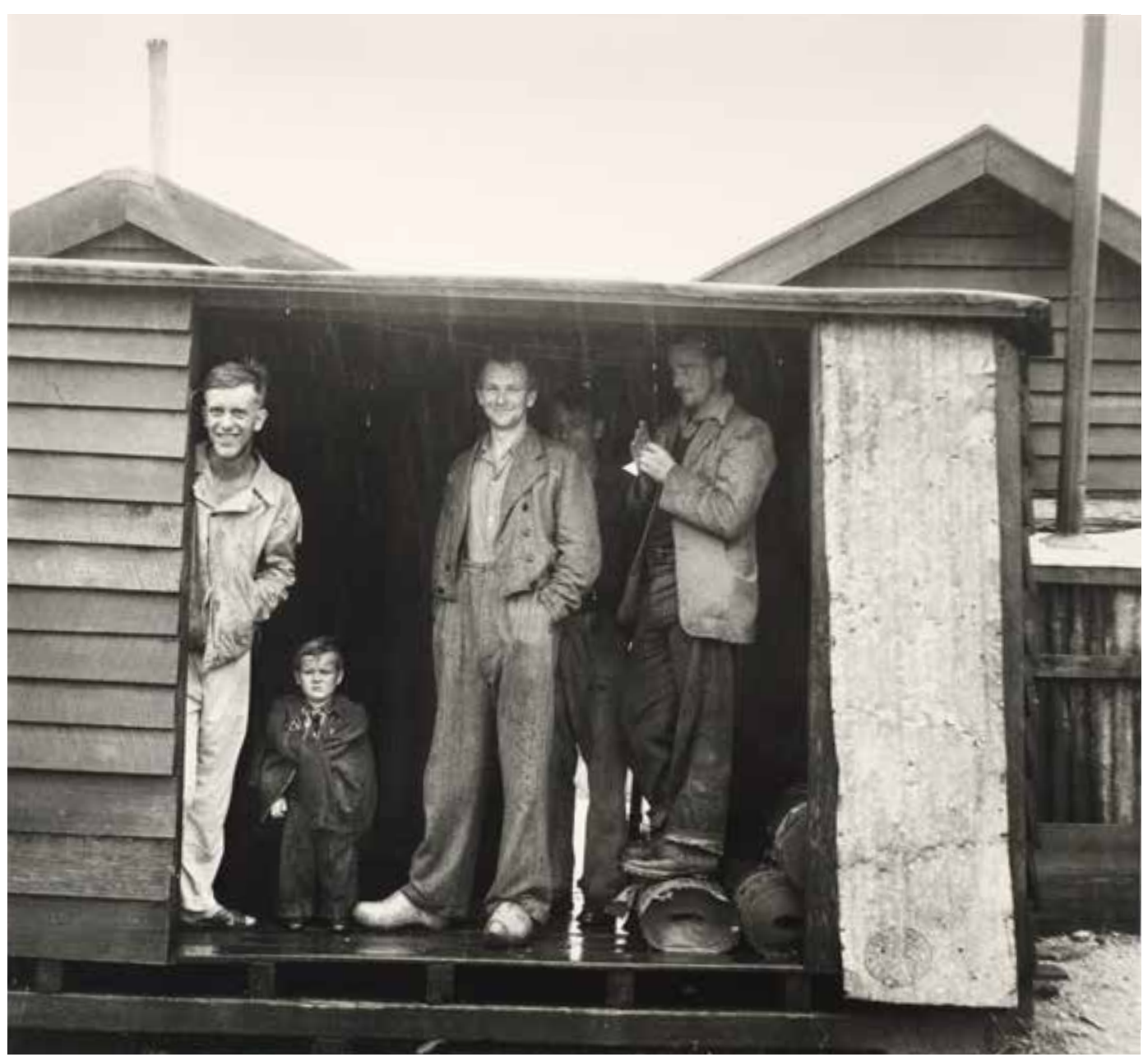

TE PAPA COLLECTION: 0.003480; Silver pine cutters sheltering from rain at Mussel Point, South Westland, 1955; Cleveland, Les 


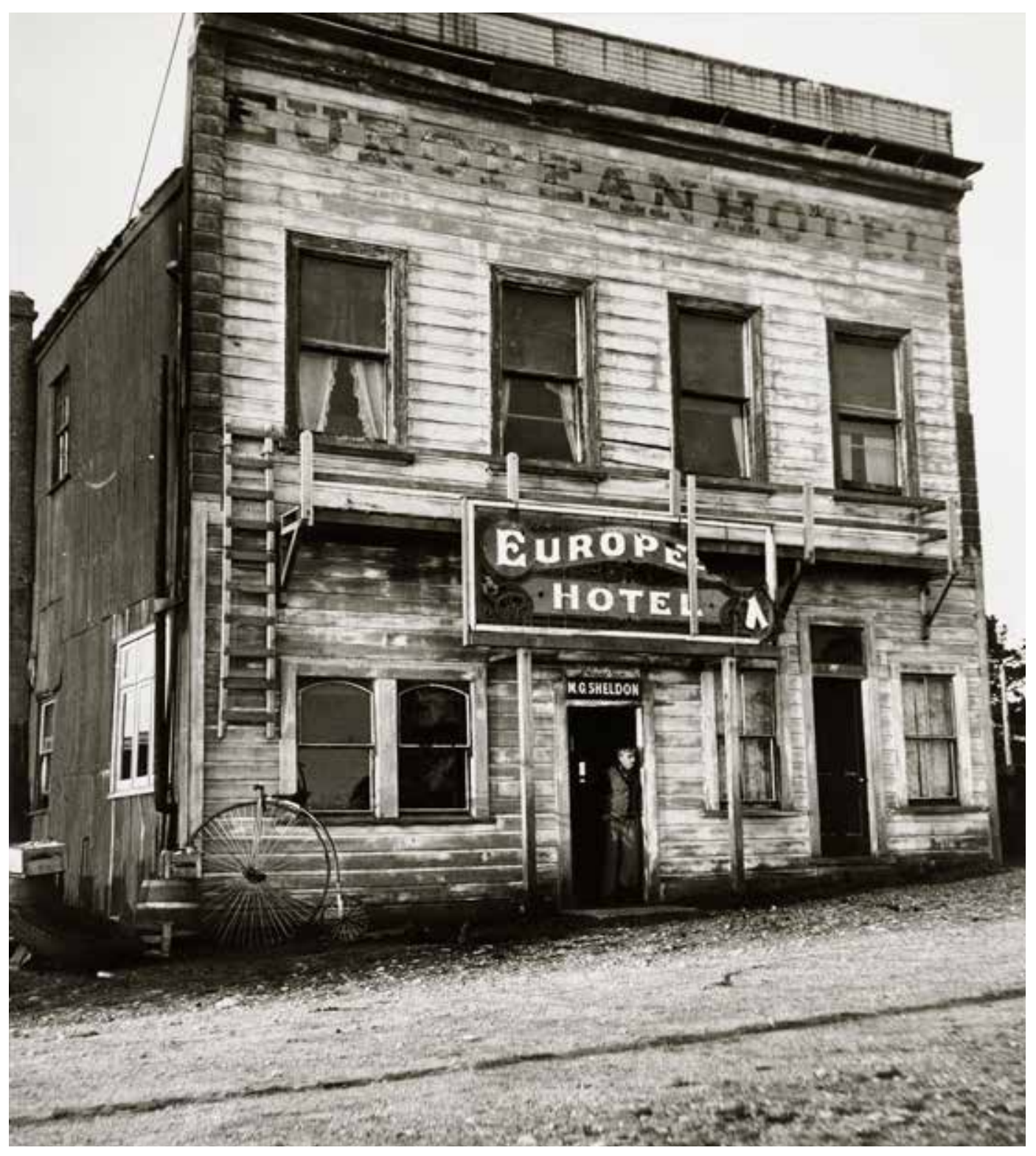

TE PAPA COLLECTION: 0.003475; The European Hotel, Charleston, Westland proprietor Mick Sheldon in doorway 1956. Cleveland, Les

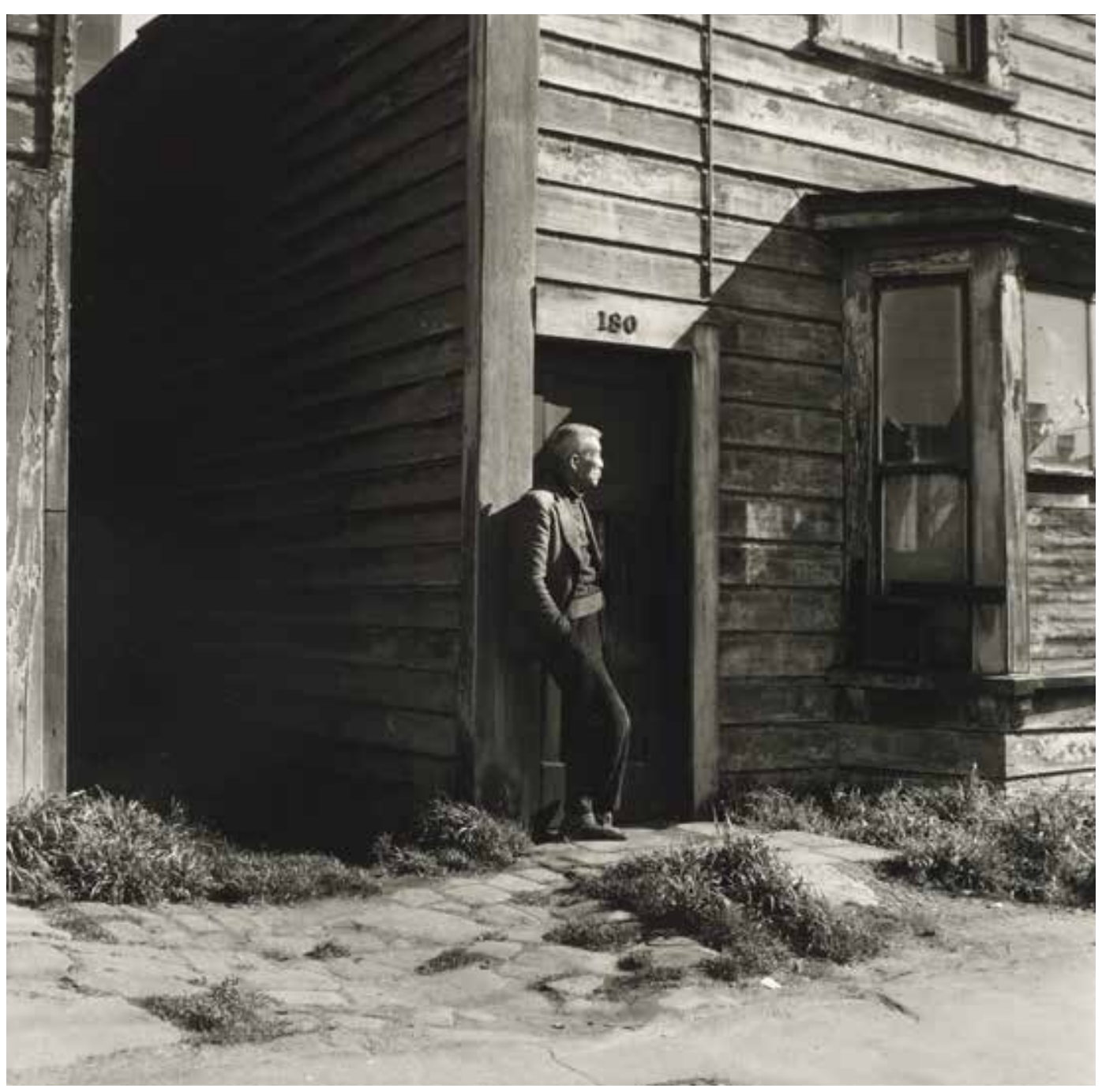

TE PAPA COLLECTION: 0.003486; Morning sun outside a pakapoo den in Taranaki Street, Wellington, 1957; Cleveland, Les 


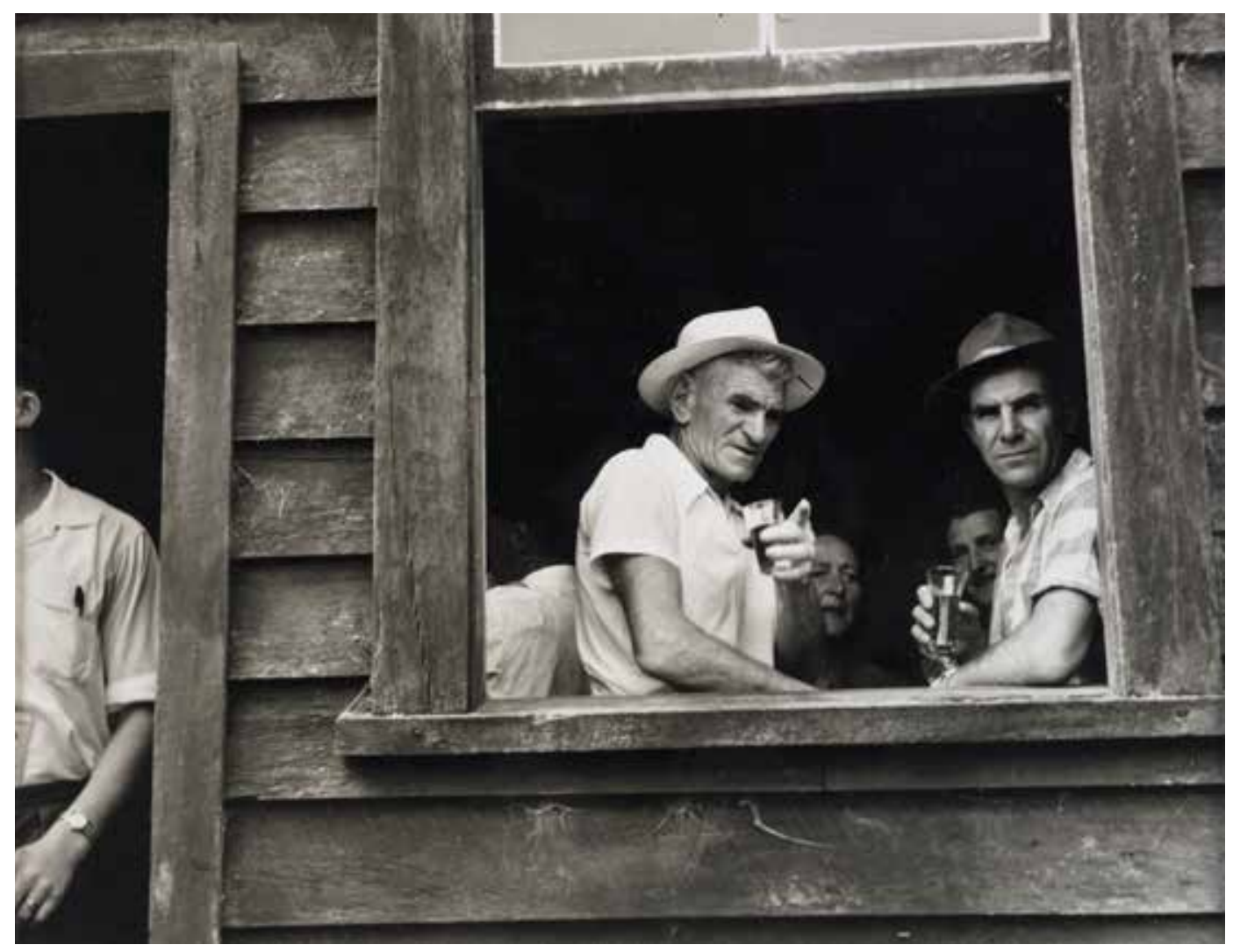

TE PAPA COLLECTION: 0.003513; Scene in bar at Kumara race meeting, Christmas 1959.

From the portfolio: PhotoForum - Les Cleveland; Cleveland, Les

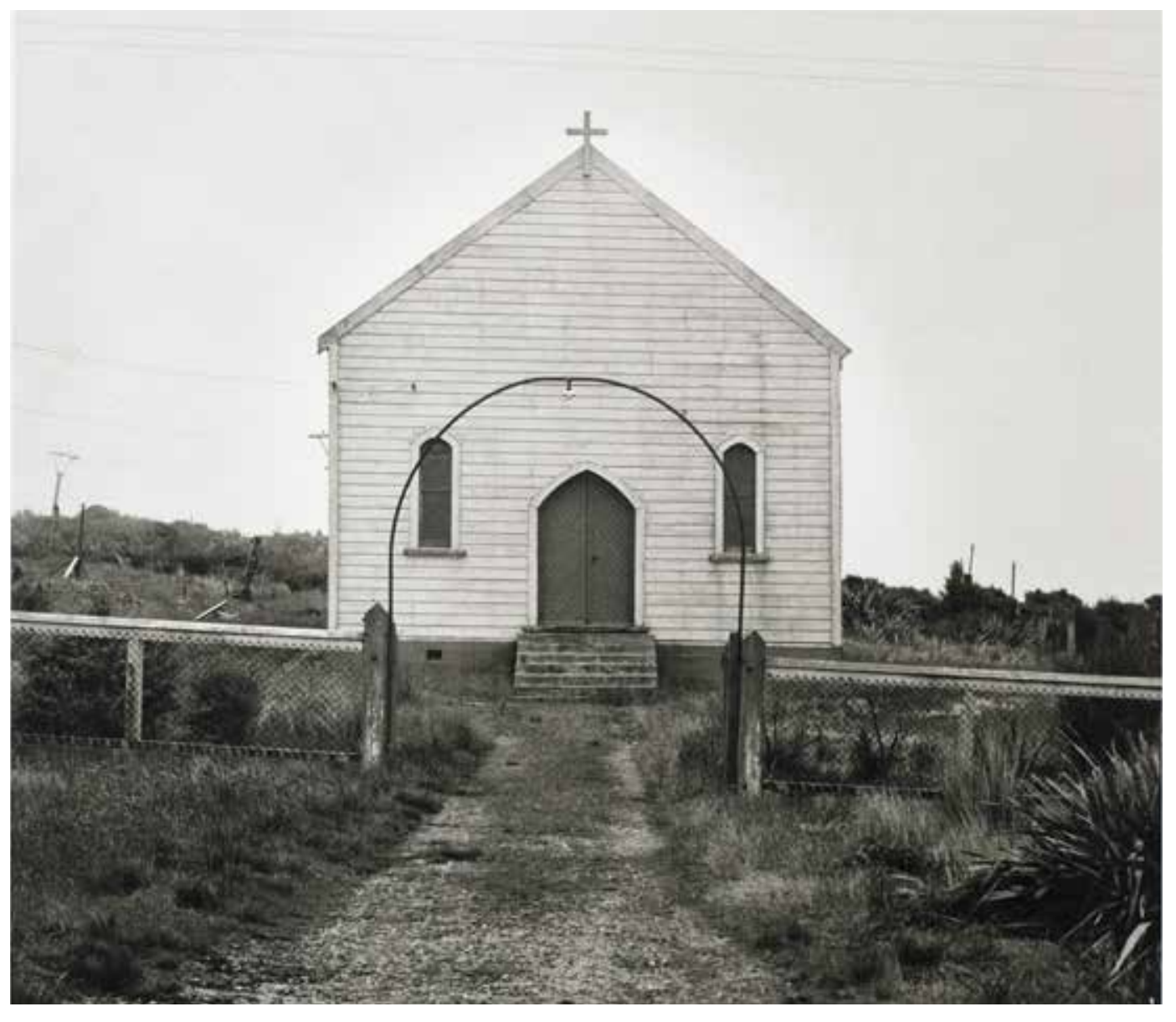

TE PAPA COLLECTION: 0.003476; Catholic Church, Denniston, Westland, 1957; Cleveland, Les 